\title{
IN VIVO ANALYSIS OF POST SPACE SEALING WITH DIFFERENT ADHESIVE MATERIALS
}

\section{ANÁLISE IN VIVO DO SELAMENTO DO CANAL PROTÉTICO COM DIFERENTES MATERIAIS ADESIVOS}

\author{
Carlos Alexandre Souza BIER \\ DDS, MSc in Endodontics by the ULBRA, Assistant Professor at the Dental School of the Federal University of Santa Maria.
}

\section{José Antônio Poli de FIGUEIREDO}

DDS, PhD in Endodontics by the USP, Coordinator of the Post-Graduation Program in Endodontics of ULBRA, Associate Professor of Dentistry at the UFRGS.

\section{Álvaro DELLA BONA}

DDS, MMedSci in Restorative Dentistry by the University of Sheffield, UK, and PhD in Biomaterials by the University of Florida, USA. Professor at the Dental School of the University of Passo Fundo (UPF).

\section{Patrícia Maria Poli KOPPER}

DDS, MSc in Endodontics by the ULBRA, Professor of Endodontics at the Dental School of the Brazilian Lutheran University at Cachoeira do Sul.

\section{José Roberto VANNI}

DDS, MSc in Endodontics by the UFPEL, Chairman Professor of Endodontics at the Dental School of the University of Passo Fundo (UPF).

\section{Simone BOPP}

MV, Master Student in Veterinary Surgery by the UFSM.

This study was conducted at the Dental Schools of Brazilian Lutheran University (ULBRA) and University of Passo Fundo (UPF).

\begin{abstract}
$T$ his in vivo study analyzed the sealing ability of two adhesives in post spaces, cyanoacrylate (Super Bonder ${ }^{\circledR}-\mathrm{Henkel}$ Loctite Adesivos Ltda., Itapevi, SP, Brazil) and Scotchbond ${ }^{\mathrm{TM}}$ Multi-Purpose (3M Dental Products, St. Paul, MN, USA), testing the hypothesis that their use would result in a decreased leakage through the remaining filling material. Forty extracted premolars ( 80 root canals) of dogs were used. The root canals were cleaned, shaped and filled by the lateral condensation technique using Sealer $26^{\mathrm{TM}}$. The post space was created removing two thirds of the filling material within the root canal. The canals were randomly divided in three groups, which were treated as follows: Group A received the Scotchbond ${ }^{\mathrm{TM}}$ MultiPurpose adhesive system; for Group B the cyanoacrylate adhesive, Super Bonder ${ }^{\mathrm{TM}}$, was employed; and no adhesive was applied into the post space for Group C (control group). A glass ionomer provisional restoration was placed allowing the sealer to set for 72 hours. Then the restoration was removed and the root canal was exposed to the oral environment for 45 days. The dogs were then killed and their jaws were removed. The post spaces were filled with India ink and the teeth were restored for 96 hours. Afterwards, the teeth were extracted and the roots were sectioned at the furcation for allocation to their specific groups. The teeth were turned transparent and the quantitative analysis of leakage was performed using light microscopy. The results showed no significant differences between groups, rejecting the initial hypothesis. Leakage occurred in a great extent in all specimens. Therefore, sealing post spaces with the adhesives used in this study was not an effective method to prevent microleakage.
\end{abstract}

UNITERMS: Root canal obturation; Microleakage; Post and core technique; Dentin-bonding agents.

\section{INTRODUCTION}

The aim of endodontic therapy is to reestablish the function of the tooth on the stomatognathic system. Several steps are conducted for that purpose, from a correct diagnosis up to the definitive restoration of the tooth. All such steps should be completed according to high technical standards and biological principles to reach satisfactory success rates.

The crown opening, chemomechanical preparation and root canal obturation constitute the endodontic triad, which aims at achieving access, cleaning and filling the root canals as hermetically as possible. The stage of chemomechanical preparation (CMP) aims at the 
cleaning, modeling and sanitation of the dental walls of the root canal. Due to the anatomical irregularities of the root canal and the limitations of the techniques and instruments employed for instrumentation, some areas of the root canal may remain untouched, therefore housing microorganisms and necrotic remnants.

Cheung ${ }^{5}$ (1995) stated that the presence of microbial activity directly or by means of its subproducts is the basic reason that leads to endodontic failure and mentioned three such situations: (1) presence of microorganisms on the external root surface in cases of persistent lesions; (2) inside the root canals, comprising remnants of the CMP; and (3) when the obturation is contaminated by saliva, therefore allowing reinfection.

For that reason, root canal obturation is important since one of its primary goals is to maintain the sanitation achieved on the previous steps, allowing the periapical tissues to rest. In this context, sealing of the root canals is crucial. The bacteria remaining from the CMP are entrapped and usually die, however some may survive entrapped for long periods of time. Therefore, sealing plays an important role because it hinders penetration of saliva, which might dissolve the endodontic sealer or even provide a substrate for bacterial growth, which in turn will trigger or maintain an aggression to the periapical tissues.

The oral cavity is known to be one of the septic environments of the organism, presenting a complex microbiota distributed on the saliva and oral ecosystems. On the daily clinical routine, root canal obturation is frequently exposed to saliva. On such situations, there is infiltration of saliva, bacteria and their subproducts. For that reason, coronal microleakage has been highlighted as one of the etiologic factors for endodontic failure ${ }^{15,16}$, 22, 23, 24 .

Endodontically treated teeth frequently require extensive rehabilitations or fixed prosthesis, therefore demanding root canal preparation for placement of a post. The aseptic control achieved by the endodontist may not be possible during these procedures. Moreover, the patient may not attend the dentist for accomplishment of the restoration soon after endodontics and therefore the provisional restorations, which are not able to avoid leakage at the interface between tooth and restoration, may be maintained for a long period of time.

In case the unfilled portion of the root canal is kept directly exposed to the oral environment without the presence of a provisional restoration, the post space may act as a small test tube containing substrate, thus providing a proper means for microbial development ${ }^{2}$. Furthermore, after preparation of the post space there will be less filling material inside the root canal to avoid penetration of bacteria or other irritants that may reach the periradicular tissues ${ }^{1,2,3,11,13,30}$.

Some procedures have been suggested in an attempt to avoid reinfection of the obturated portion of the root canal because of the concern about the possibility of coronal leakage. Some authors indicated sealing the opening of the obturated root canals ${ }^{14,19,21,29}$ and others mentioned sealing of the post space ${ }^{6,10,12,25,26,27}$. Among the materials employed, cyanoacrylate and dentin bonding agents are highlighted, because of their adhesive properties $6,12,14,17,25,26,27,29$.

Many materials are employed for different purposes in Dentistry, often without the proper support of studies on the issue. On the other hand, in vivo studies usually provide more evidences than in vitro experiments. Therefore, the purpose of the present study was to evaluate, in vivo, the sealing of the post space using either ethyl cyanoacrylate or a dentin bonding agent, testing the hypothesis that application of these adhesives decrease the dye leakage in the remaining filling material in the root canal.

\section{MATERIAL AND METHODS}

A total of 80 completely formed root canals of 8 small dogs, regardless of race, were employed on this study.

The dogs were anesthetized by means of an intramuscular injection of ketamine $15 \mathrm{mg} / \mathrm{kg}$ (Francotar ${ }^{\mathrm{TM}}$ - Virbac do Brasil Indústria e Comércio Ltda., Roseira, SP, Brazil), xylazine 1mg/kg (Virbaxyl ${ }^{\mathrm{TM}}$ $2 \%$ - Virbac do Brasil Indústria e Comércio Ltda., São Paulo, SP, Brazil) and atropine $0.044 \mathrm{mg} / \mathrm{kg}$ (Atropina 1\% FRAGA - Farmagricola S.A. Importação e Exportação, Mairipora, SP, Brazil). The dogs received $0.9 \% \mathrm{NaCl}$ intravenously and anesthetic maintenance was achieved with the same drugs throughout the procedure. The dogs were intubated and received $100 \%$ oxygen.

After disinfection of the soft tissues and teeth with a gauze pad soaked with iodized alcohol (Farmácia Escola - ULBRA, Canoas, RS, Brazil), a periapical diagnostic radiograph was taken. The small size of 3 teeth that measured less than $6 \mathrm{~mm}$ and 2 mandibular premolars presenting just one root canal fit the criteria for exclusion. Thus, 5 tooth or 10 roots were excluded from the study, reducing the number of prepared roots to a total of 70 .

Coronal access was accomplished by means of a round diamond bur \#1012 (Metalurgica Fava Indústria e Comércio Ltda., Francisco da Rocha, SP, Brazil) at highspeed (Dabi Atlante S/A Industrias Médico Odontológicas, São Paulo, SP, Brazil) with water cooling. Two separate openings were performed, which aimed at the opening of the root canal of each root, therefore keeping a hard tissue barrier between both openings. 
After establishment of the working length, $1 \mathrm{~mm}$ beyond the radiographic apex, chemomechanical preparation of the teeth was performed with $1^{\text {st }}$ series, $21 \mathrm{~mm}$ Kerr and Hedstrom files (Maillefer Instruments SA, Ballaigues, Swiss) using the serial technique. Irrigation and aspiration were done at every change of instrument, alternating $1.8 \mathrm{ml}$ of $1 \%$ sodium hypochlorite and $1.8 \mathrm{ml}$ of $17 \%$ ethylenediaminetetraacetic acid (EDTA). Root canal diameter was standardized at file \#35.

After drying with sterilized absorbent paper points (Dentsply Indústria e Comércio Ltda., Petrópolis, RJ, Brazil), the root canals were filled using the lateral condensation technique with employment of gutta-percha points \#35 (Dentsply Industria e Comercio Ltda., Petrópolis, RJ, Brazil) and B7 accessory gutta-percha points (TANARI ${ }^{\mathrm{TM}}$ - Tanariman Industrial Ltda., Manacapuru, AM, Brazil) along with the endodontic sealer Sealer 26 ${ }^{\mathrm{TM}}$ (Dentsply Indústria e Comércio Ltda., Petrópolis, RJ, Brazil). Quality of the root canal obturation was accessed by the final radiograph.

The post space was prepared immediately after obturation with Largo drills \#1 and 2 (Moyco Union Broach, York, PA, USA), calibrated with silicon stops on a slow-speed handpiece (Dabi Atlante S/A Indústrias Médico Odontológicas, São Paulo, SP, Brazil). The remaining root canal obturation was standardized as approximately $1 / 3$ of the working length, as observed on the radiograph.

The materials were randomly assigned to each group. At study completion, 24 post spaces received the Scotchbond ${ }^{\mathrm{TM}}$ Multi-Purpose adhesive system (batch \#20010213, expiry date July/2003, 3M Dental Products, St. Paul, MN, USA) making group A; 24 post spaces received the ethyl cyanoacrylate adhesive (Super Bonder ${ }^{\mathrm{TM}}$, Henkel Loctite Adesivos Ltda., Itapevi, SP, Brazil) constituting group $\mathrm{B}$; and 22 post spaces comprised the control group (C) and therefore did not receive any adhesive.

The Scotchbond ${ }^{\mathrm{TM}}$ Multi-Purpose adhesive was applied following the manufacturer's instructions, i.e. after dentin acid etching, rinsing and removal of the excess moist from the post space with absorbent paper points, the primer and adhesive were sequentially applied with paper points, excess was removed and the adhesive was light-cured for 10 seconds.

Application of the ethyl cyanoacrylate was preceded by acid etching of the dentin at the post space with $35 \%$ phosphoric acid for 15 seconds ${ }^{17}$. After thorough rinsing with spray water, the post space was dried with air and absorbent paper points and the cyanoacrylate was applied by means of an absorbent paper point \#40. The excess material was removed to achieve a thin layer.
The post spaces assigned to the control group were not submitted to any adhesive procedure.

The teeth were provisionally restored with glass ionomer cement (Vidrion $\mathrm{R}^{\mathrm{TM}}$ - SS White Artigos Dentários Ltda., Rio de Janeiro, RJ, Brazil) for 72 hours, to allow the endodontic sealer to set. After this period, the dogs were anesthetized again, the provisional restoration was removed and the post space was exposed to the oral cavity for 45 days.

According to the agenda of the animal house of the UPF, the dogs were handled by the discipline of Experimental Surgery of the Medical School and consequently euthanized after the surgical procedures with an overdose of 3\% sodium pentobarbital (Abbott Laboratórios do Brasil Ltda., São Paulo, SP, Brazil). The jaws were removed and the post spaces were filled with India ink with neutral $\mathrm{pH}$ (Trident $\mathrm{S}$. A. Indústria de Precisão, Itapui, SP, Brazil) and sealed. The specimens were placed in labeled glass bottles containing formaldehyde tablets wrapped in gauze.

According to the study design and the regulations of the Ethics Committee, the mortal remains of the dogs were placed in septic graves.

The dye was kept inside the root canals for 4 days. Afterwards, the teeth were extracted and the roots were sectioned and identified according to the experimental group.

The roots were turned transparent following the technique of Garberoglio, Bassa ${ }^{9}$, and then quantitative analysis of leakage was conducted. The degree of cervicoapical dye leakage was measured by a "blind", experienced examiner using a light microscope (GSZ, Zeiss, Germany) with 20X magnification and millimetered lenses. The scores were divided by 20 for a final scoring in $\mathrm{mm}$.

\section{RESULTS}

Some roots were fractured or worn during tooth extraction, which led to loss of further 13 roots. Therefore, the control group (C) comprised 18 roots, the dentin bonding agent group (A) was made of 20 roots and the cyanoacrylate group (B) comprised 19 roots.

Results are shown on Table 1. From all 57 roots evaluated, just one root from the cyanoacrylate group did not show total dye leakage, reaching $37 \%$ of the length of the remaining filling material. Figure 1 shows some representative images of the post space of all groups and the total dye leakage on the remaining filling material (Figure 1D). 


\section{DISCUSSION}

Most studies on leakage in Endodontics evaluate filling materials or obturation techniques, with the objective of achieving a better sealing of the root canal system $^{13,20,30}$. However, these studies demonstrated that no technique or material for obturation of the root canals avoid leakage in the absence of a permanent restoration to protect the obturation. Therefore, the hermetic sealing of the root canal system is still an ideal to be reached ${ }^{7}$.

Since contamination of the post space poses an imminent risk to the success of the endodontic treatment, the studies aiming techniques or materials that may provide better sealing or even rendering an impermeable filling material are of great importance.

Therefore, the present study aimed to evaluate the efficacy of adhesive materials to seal the post space of teeth of dogs exposed to the oral environment for 45 days.

TABLE 1- Total or partial coronal dye leakage on the three experimental groups

\begin{tabular}{lccc}
\hline Group & $\mathbf{n}$ & Total leakage & Partial leakage \\
\hline Dentin bonding agent & 20 & 20 & 0 \\
Cyanoacrylate & 19 & 18 & 1 \\
Control & 18 & 18 & 0 \\
\hline
\end{tabular}

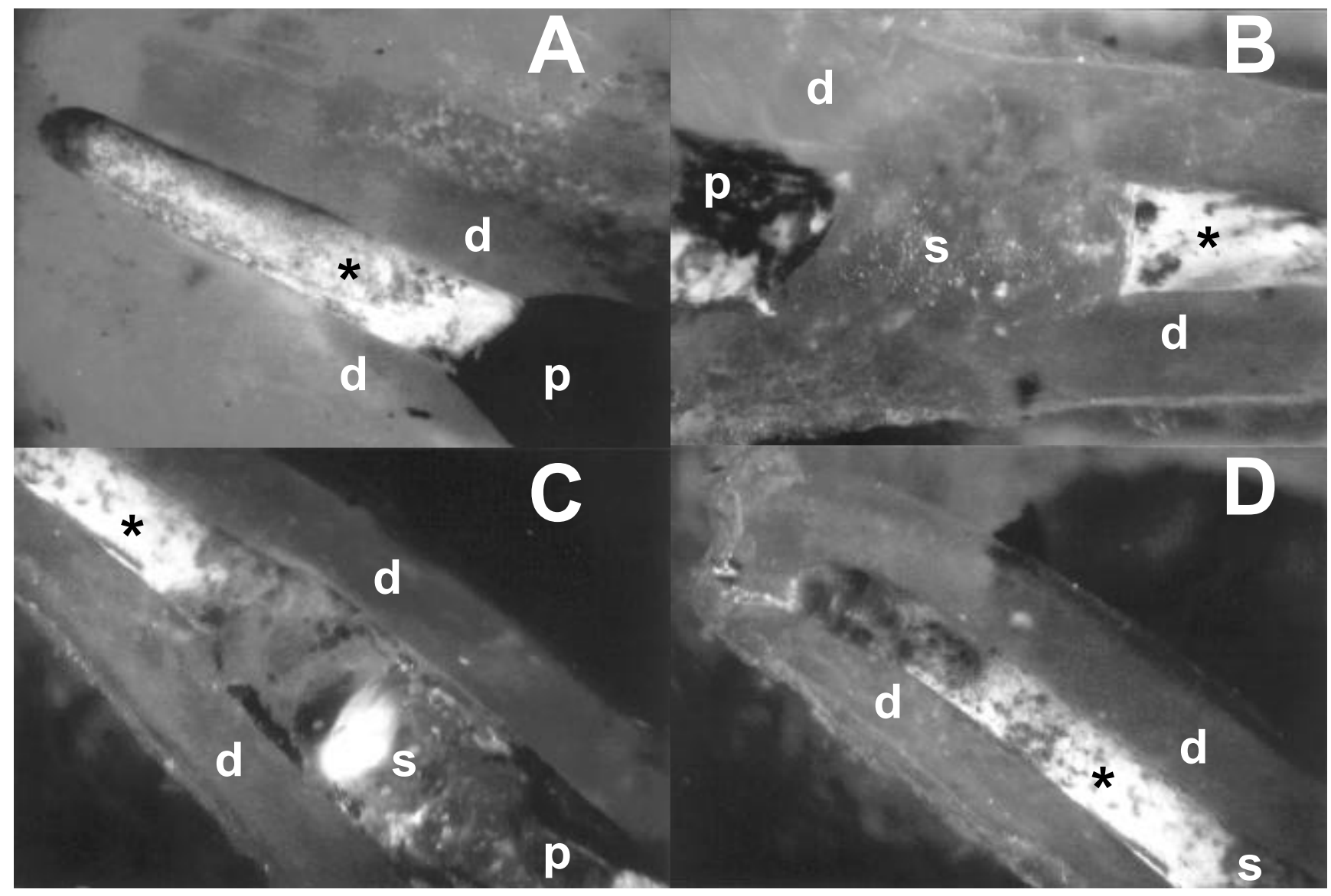

FIGURE 1- Representative photomicrographs of specimens from all three groups (X20). A - India ink in the post space ( $p$ ) contacting the filling material $\left(^{*}\right)$ (Group C). B - Group A specimen showing the post space (p) protected by the dental adhesive (s). C - Group B specimen showing the post space (p) protected by the cyanoacrylate (s). Note the material presence of the adhesives (1B and $1 \mathrm{C}$ ), which were not able to avoid the total microleakage. $\mathbf{D}-$ Apical view of same specimen shown in Fig. $1 \mathrm{C}$ revealing the total microleakage throughout the filling material $\left(^{*}\right)$.

The apical third of the root canal filled with the sealer is represented by "*”; the root dentine walls are indicated by " $d$ "; " $p$ " is the post space filled with adhesive material (s) and/or India ink 
The use of cyanoacrylate as a sealing material was based on in vitro studies that demonstrated good results with utilization of this material for retrograde filling in endodontic surgery. Moreover, recent studies indicated this material for sealing of the pulp chamber floor or post space, however with conflicting outcomes: Gomes, et al. ${ }^{12}$ achieved unsatisfactory results, whereas other studies reported good results ${ }^{14,17,25,26}$.

The same question applies to the efficacy of dentin bonding agents as materials for sealing of the post space. Vanni, et al. ${ }^{27}$, employing adhesives for sealing of the post space in vivo, observed better histological results when compared to root canal fillings of dogs exposed to the oral environment. Other studies suggested that dentin bonding agents were not efficient to prevent dye leakage ${ }^{6}$, ${ }^{29}$. The results of these studies can just be mentioned, but not compared to the present work, since Vanni, et al.. ${ }^{26}$ evaluated the histopathological reaction on the periapical tissues, whereas the other studies made use of different approaches to evaluate the degree of dye leakage to examine the sealing ability of bonding materials employed to protect the post space and the remaining filling material.

Most of the few studies on the impermeability of the post space are conducted in laboratory (in vitro). Even though these trials allow the control of important variables that may interfere with the results, they present limitations as to the peculiar conditions of the oral cavity, such as: masticatory activity, thermal variation, oral microbiota, variations in salivary flow rate and food impaction.

This study aimed at reducing the limitation of in vitro studies through employment of dogs as an experimental model, testing the hypothesis that the application of adhesives on the post space exposed to the oral conditions may avoid or reduce dye leakage.

Previous studies suggested the time of exposure to the oral environment as 45 days. Magura, et al. ${ }^{16}$ (1991) stated that, if the filling material is exposed to saliva for 90 days, endodontic retreatment must be done, highlighting that leakage may occur more quickly in teeth submitted to post space preparation. The results of other authors $1,2,3,11,13,30$ supported this statement, since microbial leakage affected the entire extension of the root canal submitted to post preparation in less than 90 days on these studies. The contact between the endodontic sealer and oral fluids leads to a gradual degradation, which favors coronal leakage. Valera, et al. ${ }^{25}$ made use of a period of 45 days to conduct a comparative evaluation of the sealing ability of two cyanoacrylates concerning the in vitro exposure of the post space to artificial saliva.

Studies on microleakage make use of small molecular size dyes that do not directly express the pattern of microbial leakage that occurs on the clinical situation. If there is an empty space where the dye was able to penetrate, there is no hermetic sealing and consequently a microbial invasion is likely to occur. Studies have demonstrated that, when teeth are turned transparent, the India ink is kept stable, whereas other dyes tend to discolor, leading to incorrect outcomes ${ }^{20,23}$.

In the present study, the teeth were turned transparent to evaluate the degree of dye leakage. This procedure provided a tridimensional visualization of the specimens, allowing the measurement of data in all sides and at the point of largest leakage. In several situations, leakage seemed to be minimal or absent. However, when the tooth was rotated under the microscope, total leakage could be observed. The possibility of a complete tridimensional analysis of the dental structure is an important advantage achieved when teeth are turned transparent for evaluation of leakage.

Analysis of the results demonstrate that the adhesive materials did not avoid dye leakage on the remaining filling material after 45 days of contact with the oral environment, with no significant differences when compared to the mean leakage value of the control group. The total leakage in almost all root canals after 45 days indicates the presence of gaps within the filling material, what may be favorable to the bacteria in detriment of the combination of filling material and adhesive, therefore jeopardizing the success of treatment.

The results of this study agree with the findings of Zaia, et al. ${ }^{29}$. These authors concluded that the dentin bonding agent Scotchbond ${ }^{\mathrm{TM}}$ Multi-Purpose, employed on the pulp chamber floor, yielded results that were statistically equal to the unsealed control group.

Cipelli, et al. ${ }^{6}$ evaluated the sealing ability of the dentin bonding agent on the root canal walls. The results demonstrated similar means between the groups with and without the dentin bonding agent. According to the authors, the fact that adhesives may only be completely cured in the absence of oxygen may lead to a high degree of dye leakage.

Vanni, et al. ${ }^{27}$ demonstrated better histological results on post space sealed with dentin bonding agents in relation to the control group (no sealing). Even though the present work and the aforementioned study ${ }^{27}$ have employed similar in vivo experimental design, analyses of the results have different approaches and can not be compared.

Leite $^{14}$ observed that the layers formed by Super Bonder $^{\mathrm{TM}}$ and by the Scotchbond ${ }^{\mathrm{TM}}$ Multi-Purpose reduced the coronal leakage when applied on the openings of the root canals, whereas on the control group (no sealing) the dye invariably reached the apical third. Leakage was limited to the cervical third on the sealed groups. Therefore, and as in the present study, the use of 
adhesive into the post space did not prevent total dye leakage.

Previous studies demonstrated that cyanoacrylates can remarkably reduce coronal leakage in endodontic obturations exposed to the oral cavity ${ }^{17,25,26}$. These studies had an in vitro design and presented several limitations because they do not reproduce clinically important variables.

A poor bonding between the restorative material and the dental structure may lead to leakage of bacteria and molecular fluids on the interface between tooth and restoration and may give rise to an unsuccessful restorative treatment ${ }^{4}$. Whereas enamel bonding is based on a solid scientific knowledge, dentin bonding is still challenging, especially because it comprises a substrate that is more morphologically heterogeneous and more physiologically dynamic than the enamel. In addition to this morphological aspect, the differences between the coronal dentin and the root dentin, with the latter having less tubules and presents hypomineralized structures (granular layer of Tomes; interglobular areas), may also impair bonding. Bonding to the dentin substrate is known to be largely dependent on the formation of a hybrid layer that corresponds to a mesh of collagen fibers exposed after acid etching, which are enfolded by the primer and adhesive and provide bonding to the restorative material. However, sealing of the post space also requires bonding to the gutta-percha points.

Bonding of cyanoacrylates to dentin is impaired because of its easy degradation through water hydrolysis ${ }^{4}$ ${ }^{8}$. The manufacturer of this adhesive mentions that, in case of unintended bonding to the skin, thorough rinsing with water combined to attrition is able to remove the product. Therefore, it is assumed that application of cyanoacrylate placed on the post space with saliva, together with the masticatory impact, give rise to a weak bonding, which did not prevent dye leakage.

Some recent studies have further demonstrated that sodium hypochloride negatively influences the bonding strength of dentin bonding agents and resin cements ${ }^{18,28}$. This may explain the poor bonding that allowed leakage on the bonding agent in the present study, since $1 \%$ sodium hypochloride was employed during the CMP.

In a recent in vivo study, $\operatorname{Kopper}^{13}$ (2003) compared three endodontic sealers exposed to saliva for 45 days and observed remarkable leakage with the Sealer $26^{\mathrm{TM}}$. The author further observed that employment of the $\mathrm{AH}$ Plus $^{\mathrm{TM}}$ sealer almost avoided dye leakage, therefore stressing the importance of the materials on root canal obturation as the last barrier to coronal leakage. Further studies are required to solve the problem of exposure of filling material to the oral cavity, highlighting the employment of techniques and materials to avoid or reduce coronal leakage.

Thus, on the basis of the descriptive statistical analysis of the data, the results did not demonstrate any differences between the three study groups, rejecting the initial hypothesis. There was dye leakage on the remaining filling material in almost all roots analyzed.

\section{RESUMO}

Esse estudo in vivo analisou a capacidade de selamento do canal protético com dois adesivos, o Super Bonder ${ }^{\circledR}$ (Henkel Loctite Adesivos Ltda., Itapevi, SP) e o Scotchbond ${ }^{\circledR}$ Multi-Purpose (3M Dental Products, St. Paul, MN, EUA), testando a hipótese de que a aplicação desses adesivos resulta em menor infiltração de corante no material obturador remanescente. Quarenta dentes prémolares ( 80 canais) de cães foram obturados pela técnica da condensação lateral usando o cimento endodôntico Sealer 26®. O canal protético foi preparado removendose $2 / 3$ da obturação do canal radicular. Os canais preparados foram distribuídos, aleatoriamente, em três grupos: no grupo $\mathrm{A}$, foi realizado o selamento do canal protético com o adesivo dentinário; no grupo $\mathrm{B}$, esta impermeabilização foi realizada com o Super Bonder®; e no grupo $\mathrm{C}$, controle, não foi aplicado qualquer material às paredes do canal protético. Os dentes foram selados, provisoriamente, com cimento de ionômero de vidro por 72 horas, objetivando a presa do cimento endodôntico. Removido o selamento coronário, os canais ficaram expostos ao meio bucal por 45 dias, quando os cães foram mortos e os maxilares removidos. Tinta nanquim foi colocada no canal protético e os dentes foram selados por 96 horas. Depois de extraídos, os dentes foram seccionados na região da furca e cada raiz alocada em seu respectivo grupo. Feita a diafanização, foi realizada a análise quantitativa da infiltração do corante com lupa esteroscópica. Os resultados mostraram não haver diferenças entre os três grupos experimentais, negando a hipótese inicial. Houve infiltração do corante no remanescente obturador de todas as raízes analisadas.

UNITERMOS: Obturação do canal radicular; Pinos dentários, Adesivos dentinários.

\section{REFERENCES}

1- Alves J, Walton R, Drake D. Coronal leakage: endotoxin penetration from mixed bacterial communities through obturated, post-prepared root canals. J Endod. 1998; 24(9):587-91.

2- Barrieshi KM, Walton RE, Johnson WT, Drake DR. Coronal leakage of mixed anaerobic bacteria after obturation and post space preparation. Oral Surg Oral Med Oral Pathol Oral Radiol Endod 1997; 84(3):310-4. 
3- Borba MV. Avaliação in vitro da infiltração microbiana cervicoapical em canais radiculares preparados para pino. Canoas; 2001. [Dissertação de Mestrado - Faculdade de Odontologia, Universidade Luterana do Brasil].

4- Chain MC, Araujo RM, Teixeira LC. Adesivos dentinários: uma nova era na Oodontologia. Rev Gaucha Odontol 1994; 42(3):134-8.

5- Cheung B S. Endodontic failure - changing the aproach. Int Dent J 1995; 46(3):131-8.

6- Cipelle SR, Bombana AC, Antoniazzi, JH. Avaliação "in vitro", após preparo de espaço para retentor intra-radicular, da impermeabilização da dentina diante da aplicação de diversos produtos. Rev Pos Grad 1995; 2(5):16-21.

7- Figueiredo JAP, Estrela C. Obturação do canal radicular. In: Estrela C, Figueiredo J A P. Endodontia: princípios biológicos e mecânicos. São Paulo: Artes Médicas; 1999. Cap. 18, p. 655-96.

8- Fukushi Y, Fusayama T. Efect of cyanoacrylate treatment of cavity walls. J Dent Res 1980; 59(4):662-9.

9- Garberoglio R, Bassa S. O dente transparente. Ars Cvrandi Odontologia 1983; 9(3):5-7.

10- Guerra JA, Skribner JE, Lin LM. Influence of a base on coronal microleakage of post prepared teeth. J Endod 1994; 20(12):589-91.

11- Gish SP, Drake DR, Walton RE, Wilcox L. Coronal leakage: bacterial penetration through obturated canals following post preparation. J Am Dent Assoc 1994; 125(10):1369-72.

12- Gomes APM, Oliveira LD, Camargo CHR, Balducci I. Avaliação da infiltração marginal por corante em obturações de canais radiculares preparados para núcleo, em virtude do material de preenchimento ou impermeabilização do remanescente radicular. Rev Odontol Unesp 1999; 28(1):147-60

13- Kopper PMP. Análise comparativa, in vivo, da capacidade de selamento de três cimentos endodônticos em dentes de cães. Canoas; 2003. [Dissertaçãode Mestrado - Faculdade de Odontologia, Universidade Luterana do Brasil].

14- Leite APP. Avaliação “in vitro” de películas seladoras na prevenção da microinfiltração coronária, pós-obturação de canais radiculares. Campinas; 1997. [Dissertação de Mestrado - Faculdade de Odontologia de Piracicaba, Universidade Estadual de Campinas].

15- Madison S, Swanson K, Chiles S A. An evaluation of coronal microleakage in endodontically treated teeth. Part II: sealer types. J Endod 1987; 13(3):109-12.

16- Magura ME, Kafrawy A, Brown CE, Newton CW. Human saliva coronal microleakage in obturated root canals: an in vitro study. J Endod 19991; 17(7):324-31.

17- Maniglia CAG; Maniglia AB, Picoli F, Vinha D, Rodrigues RTT. Avaliação in vitro do selamento da proporcionado por diferentes agentes seladores da câmara pulpar de molares inferiores [resumo n. Ia027]. Pesqui Odontol Bras 2002; 16(Supl):35.

18- Morris MD, Lee KW, Agee KA, Bouillaguet S, Pashley D H. Effects of $\mathrm{NaOCl}$ and RC Prep on bond strengths of resin cement to endodontic surface. J Endod 2001; 27(12):753-7.

19- Pisano DM, Difiore PM, Mcclanahan SB, Lautenschlager E P, Duncan JL. Intraorifice sealing of gutta-percha obturated root canals to prevent coronal microleakage. J Endod 1998; 24(10):659-62.
20- Ravanshad S, Torabinejad M. Coronal dye penetration of the apical filling materials after post preparation. Oral Surg Oral Med Oral Pathol Oral Radiol Endod 1992; 74(5):644-7.

21- Roghanizad N, Jones J J. Evaluation of coronal microleakage after endodontic treatment. J Endod 1996; 22( 9):471-3.

22- Saunders, WP, Saunders EM. Coronal leakage as a cause of failure in root-canal therapy: a review. End Dent Traumatol 1994; 10(3):1058

23- Swanson K, Madison S. An evaluation of coronal microleakage in endodontically treated teeth. Part I: time periods. J Endod 1987; 13( 2):56-9.

24- Torabinejad M, Ung B, Kettering JD. In vitro bacterial penetration of coronally unsealed endodontically treated teeth. J Endod 1990; 16(12):566-9.

25- Valera MC, Barbieri M, Menezes M M, Guimarães MP. Efeito da saliva sobre canais obturados, preparados para núcleo e impermeabilizados com cianoacrilatos. J Bras Endo/Pério 2000; 1(1):67-71

26- Valera MC, Cia D. Impermeabilização da obturação do canal radicular após preparo para núcleo. Rev Gaúcha Odontol 2000; 48(3):157-60.

27- Vanni JR, Figueiredo JAP, Della Bona A, Hartmann MS M, Garbin CA, Manfredi D. Bonding endodontically treated root canal surfaces to prevent coronal leakage. J Dent Res 2001; 80(sp issue):191.

28- Vichi A, Ferrari M, Davidson CL. In vivo leakage of an adhesive system with and without $\mathrm{NaOCl}$ as pretreatment. J Dent Res 1997; $76($ sp. issue): 398 .

29- Zaia A A, Nakagawa I, De Quadros I, Gomes BPFA, Ferraz CCR, Teixeira FB, Souza-Filho FJ. An in vitro evaluation of four materials as barriers to coronal microleakage in root-filled teeth. Int Endod J 2002; 35(9):729-34.

30- Zucco LR. Avaliação da infiltração coronária em canais obturados e preparados para pino. Canoas; 2001. [Dissertação em Mestrado Faculdade de Odontologia, Universidade Luterana do Brasil]

\section{Correspondence to: \\ Carlos Alexandre Souza Bier \\ Centro de Ciências da Saúde \\ Departamento de Estomatologia \\ Curso de Odontologia - UFSM \\ Rua Floriano Peixoto, 1184 \\ CEP 97015-372 Santa Maria, RS. \\ Telephone +55 (55) 2223444 branch 284. \\ Email: alexandrebier@terra.com.br}

